Editorial

\title{
Perspectives on Human Trafficking and Modern Forms of Slavery
}

\author{
Siddharth Kara \\ Carr Center for Human Rights Policy, Harvard Kennedy School, USA; E-Mail: siddharth_kara@hks.harvard.edu
}

Submitted: 22 May 2017 | Published: 23 June 2017

\begin{abstract}
Migration, technology, law, and measurement are each among the most topical areas of enquiry in the global human trafficking field, with much work remaining to be done in these and other areas. Beneath these particular intersections lies a crucial truth-slavery is a global business that thrives on the callous exploitation of the labor activity of a vast and highly vulnerable subclass of people whose brutalization is tacitly accepted by every participant in the global economy, from corporations to consumers. I am deeply gratified to edit Social Inclusion's second issue on human trafficking and modern slavery. The level of scholarly interest in these topics continues to grow, and in this issue the authors explore some of the most pressing manifestations of human trafficking around the world.
\end{abstract}

\section{Keywords}

child trafficking; forced labor; human trafficking; labor trafficking; migration; sex trafficking; slavery

\section{Issue}

This editorial is part of the issue "Perspectives on Human Trafficking and Modern Forms of Slavery", edited by Siddharth Kara (Harvard Kennedy School, USA).

(C) 2017 by the author; licensee Cogitatio (Lisbon, Portugal). This article is licensed under a Creative Commons Attribution 4.0 International License (CC BY).

I am deeply gratified to edit Social Inclusion's second issue on human trafficking and modern slavery. The level of scholarly interest in these topics continues to grow, and in this issue the authors explore some of the most pressing manifestations of human trafficking around the world. Articles by Ventrella (2017) and by Mandić (2017) explore the highly topical issue of the confluence of smuggling and human trafficking in the context of distress migration from northern Africa and the Middle East into the European Union. Migration will always remain central to the contemporary human trafficking crisis, and it is vital that we learn how traffickers prey on their victims in the context of mass migration events in order to devise more effective preventions and protections. The evolution of law on human trafficking is also a fertile area of enquiry. Craig (2017) analyzes the UK's Modern Slavery Act of 2015, rightfully lauded as the gold standard in anti-slavery legislation at the time, but nevertheless falling short in several crucial areas. Measurement also remains a central issue in the antislavery field, and Rudolph and Schneider (2017) present new methods of measuring human trafficking in an effort to address this data gap in the field. Another pressing area of devel- opment with human trafficking is the role technology plays in facilitating many aspects of a traffickers' business. Backpage.com has been at the center of heated debates in the United States on the liability, or lack thereof, of a website that hosts third-party advertisements that sell women and children for commercial sex. Swanson (2017) explores the legal and practical vectors of this debate incisively. Kaufka Walts (2017) explores a topic that has received very little research attention-child labor trafficking in the United States, filling yet another lacuna in research. Finally, Bain (2017) comments on the role that entrepreneurship can play in the fight against human trafficking.

Migration, technology, law, and measurement are each among the most topical areas of enquiry in the global human trafficking field, with much work remaining to be done in these and other areas. Beneath these particular intersections lies a crucial truth-slavery is a global business that thrives on the callous exploitation of the labor activity of a vast and highly vulnerable subclass of people whose brutalization is tacitly accepted by every participant in the global economy, from corporations to consumers. The relationship between slavery 
and global supply chains requires significant scholarly attention. Slavery touches our lives every day, whether we know it or not, be it from the food we eat, the clothes we wear, or the technology devices that make our modern lives possible. I call upon all researchers, activists, and scholars to continue devoting their energies to deepening our understanding of how and why slavery persists in the world, what are the forces underpinning slavery that may be vulnerable to disruption, and what each of us can do to promote efforts to combat this crime. Slavery is an ignoble and archaic stain on humanity born during a time when it was universally accepted that a substantial segment of humanity could be treated as property. While no right-minded person continues to believe that any human being should be treated like chattel, the underbelly of our global economic order thrives on shadow labor markets which, in many cases, amount to treating people as property, or worse. Worse, because human life has in many ways lost a considerable amount of value across the centuries, given the immense population of evervulnerable and deeply impoverished people who can be transported quickly and inexpensively around the world for the purpose of slave-like exploitation. Minimal transport time and costs mean a person can be exploited for just a few months and still generate substantial profits for his or her exploiter, be discarded, and replaced relatively easily. This shift in the speed and inexpensiveness of slavery has had profound consequences on the profitability and pervasiveness of the system and led to its increas- ing permeation across the global economy. Chief among many imperatives regarding slavery must be a deeper understanding of the economic functioning of slavery, and how our global economic order can be cleansed of this ignoble offense.

\section{References}

Bain, C. (2017). Entrepreneurship and innovation in the fight against human trafficking. Social Inclusion, 5(2), 81-84.

Craig, C. (2017). UK's modern slavery legislation: An early assessment of progress. Social Inclusion, 5(2), 16-27.

Kaufka Walts, K. (2017). Child labor trafficking in the United States: A hidden crime. Social Inclusion, 5(2), 59-68.

Mandić, D. (2017). Trafficking and Syrian refugee smuggling: Evidence from the Balkan route. Social Inclusion, 5(2), 28-38.

Rudolph, A., \& Schneider, F. (2017). International human trafficking: Measuring clandestinity by the structural equation approach. Social Inclusion, 5(2), 39-58.

Swanson, E. (2017). Freedom, commerce, bodies, harm: The case of backpage.com. Social Inclusion, 5(2), 3-15.

Ventrella, M. (2017). Identifying victims of human trafficking at hotspots by focusing on people smuggled to Europe. Social Inclusion, 5(2), 69-80.

\section{About the Author}

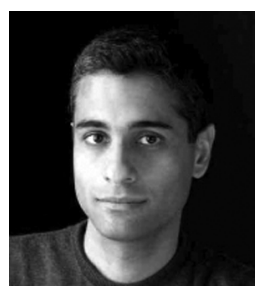

Siddharth Kara is the Director of the Program on Human Trafficking and Modern Slavery at the Harvard Kennedy School of Government. He is the author of numerous books and articles on contemporary slavery, including Sex Trafficking: Inside the Business of Modern Slavery, Bonded Labor: Tackling the System of Slavery in South Asia, and Modern Slavery: A Global Perspective. Kara's first book has been made into a Hollywood film, Trafficked. Across seventeen years of research, Kara has traveled to more than sixty countries on six continents to personally document several thousand slaves of all kinds. 